\title{
MENGUJI KHARISMA KYAI DALAM KEHIDUPAN MASYARAKAT MADURA JEMBER JAWA TIMUR
}

\author{
Al Khanif \\ Dosen UNEJ Jember, Ketua Pusat Studi HAM UNEJ Jember \\ Email:farasix@yaboo.com
}

\begin{abstract}
Charisma of kyai has been facing more socio-cultural challenge over time due to the development of society. The intervention of government to eliminate poverty and enhance the quality of education, globalization, modernization as well as the change of paradigm within society has influenced paternalistic tradition. However, the role of kyai in Madurese society has performed differently. In socio-cultural tradition, kyai has still played significant role to shape people's understanding about world view especially on religious and cultural values. Additionally, kyai has also still influenced people's political view and even has more power to shape its society by challenging its organization structural birearkhy. This paper comes with conclusion that kyai for Madurese people is still charismatic because they have extra ordinary knowledge to response social problem. Additionally, people perceive kyai as a representative of creative minority group.
\end{abstract}

Keywords: Charisma, Kyai, Madurese, Power

\begin{abstract}
Abstrak
Karisma seorang kyai secara berangsur-angsur mengalami berbagai tantangan sosial budaya dari waktu-kewaktu dikarenakan perkembangan masyarakat. Intervensi pemerintab dalam usaba menanggulangi kemiskinan dan meningkatkan kualitas pendidikan, globalisasi, modernisasi sepertibalnya perubaban paradigma sosial telab mempengarubi tradisi paternalistic. Namun demikian peranan kyai bagi masyarakat Madura berbeda. Dalam tradisi sosial budaya, kyai masib memainkan peranan penting untuk membentuk pemabaman masyarakat tentang pandangan agama dan nilai-nilai budaya. Terlebib lagi kyai juga masib dipengarubi pandangan politik dari masyarakat yang terkadang memiliki kekuatan untuk membentuk masyarakat dengan birarki structural organisasinya.
\end{abstract}


Pada akbirnya dapat disimpulkan babwa kyai bagi masyarakat Madura masih karismatik karena mereka memiliki kemampuan lebih dalam merespon berbagai permasalahan sosial. Terlebih lagi masyarakat menganggap kyai sebagai wakil kelompok minoritas yang kreatif.

Kata kunci: Karisma, kyai, masyarakat Madura, Kekuatan

\section{Latar Belakang}

Kompleksitas dunia ke-kyai-an masih relevan untuk dikaji dari berbagai disiplin ilmu karena konteks lokalitas masyarakat sebagai basis sosial kyai terus mengalami perubahan. Perubahan sosial di masyarakat sebagai basis sosial kyai tentu berpengaruh terhadap pergeseran-pergeseran status dan fungsi kyai dalam masyarakat tersebut. Sehingga status sosial kyai sangat dipengaruhi oleh apresiasi dari masyarakat setempat. Semakin tinggi apresiasi yang diberikan oleh masyarakat maka semakin tinggi pula status sosial kyai yang bersangkutan yang pada akhirnya masyarakat memposisikan kyai sebagai panutan atau patron.

Kyai yang oleh Geerzt dianggap berperan dalam memberikan pemahaman kepada masyarakatnya tentang apa yang terjadi di tingkat nasional tidak saja menjadi perantara, melainkan juga sebagai pemain budaya dalam masyarakatnya (Turmudi, 2003: 7). Mereka tidak hanya menentukan nilai sosial apa saja yang patut untuk ditradisi-kan dalam masyarakatnya melainkan juga memainkan peran mereka dan turut terlibat aktif dalam kehidupan sosial dalam masyarakat tersebut. Kyai berbaur dengan masyarakat dalam berbagai kegiatan yang ada di dalam masyarakat baik sebagai perantara maupun sebagai pemain dalam rutinitas tersebut. Pola rutinitas seperti ini kemudian menjadikan hubungan antara kyai dengan masyarakat menjadi erat dimana kyai sebagai tokoh kharismatik menjadi tokoh kreatif minoritas 'creative minority groups' karena berhasil menanamkan doktrin terhadap para pengikutnya.

Kharisma dengan segala bentuknya selalu saja berujung pada kuasa sehingga memunculkan tafsir hegemonik dari pemegang charisma tersebut. Dalam konteks masyarakat tradisional, hegemoni kharisma kyai berpengaruh sangat kuat terhadap pola pikir dan 
sistem kepercayaan masyarakat setempat. Konsekuensinya, mobilisasi massa arus bawah akan terfragmentasi oleh sekat-sekat kepentingan dari kyai-kyai tersebut karena adanya budaya patron client dan sistem budaya paternalistik yang memposisikan kyai sebagai pelaku utama di masyarakat.

Hegemoni kyai terjadi karena pola hubungan antara kyai dan masyarakat menempatkan kyai pada posisi penerjemah yang memberikan penjelasan dalam konteks agama dan mengklarifikasi berbagai masalah bangsa pada umumnya (Turmudi, 2003: 7). Disinilah kemudian kyai berperan dalam membentuk pemahaman para pengikutnya terhadap fenoma yang terjadi di masyarakat. Peran tersebut kemudian menggiring para pengikut kyai untuk bisa memantapkan status mereka dalam kesetiaan yang diimplementasikan dalam kehidupan sosial masyarakat sehari-hari.

Namun sejalan dengan perkembangan jaman, pola hubungan antara kyai dan masyarakat mulai dipertanyakan lagi. Ada beberapa faktor yang bisa mengubah pola hubungan tersebut seperti modernisasi, globalisasi, dan perubahan pola pendidikan di masyarakat. Misalnya, munculnya generasi muda santri berkarakter modern tentu berpengaruh pada perilaku, pemikiran dan sikap mereka terhadap kyai. Kelompok santri modern ini pada umumnya merasa lebih bebas untuk mengkaji dan mengevaluasi sikap kyai, tidak saja dalam wilayah politik melainkan juga dalam hal khilafiyah (Turmudi, 2003: 7). Selain itu, munculnya para intelektual Muslim juga ikut merubah pola hubungan antara kyai dan masyarakat. Kelompok ini bahkan sering menyerang patronase kyai yang dianggap telah melakukan cultural oppression karena telah melakukan pemasungan berfikir kepada para pengikutnya (Jaiz, 2003: 54).

Upaya dari pemerintah untuk meningkatkan taraf hidup warga negara juga bisa berdampak pada pola hubungan antara kyai dan masyarakat (Turmudi, 2003: 4). Wilayah operasi negara yang bertujuan untuk memperbaiki kualitas pendidikan, kehidupan, dan kesehatan masyarakat ini membuat semua hal yang dulunya dibawah penguasaan agama dan otoritas kyai menjadi wilayah umum. Sehingga hegemoni kyai dalam beberapa hal menjadi kabur. Selain itu, kyai juga harus menghadapi dampak modernisasi dengan 
berbagai atributnya, mengikuti konteks kekinian yang terus berlangsung.

Di lihat dari perspektif yang lebih umum, perubahan-perubahan dalam posisi sosial kyai dan persepsi umat Islam merupkan efek dari perubahan-perubahan besar dalam struktur sosial yang terjadi di berbagai daerah. Perubahan sosial tersebut menyebabkan perubahan struktural di masyarakat seperti terjadinya perubahan pola hubungan antar individu dan antar masyarakat dari komunal menjadi lebih individual dan juga perubahan pola kultural masyarakat seperti terjadinya perubahan pola pikir dan orientasi hidup.

Masyarakat Madura dengan segala kompleksitas budaya dan dinamika kehidupan masyarakatnya memang masih menarik untuk dikaji. Masyarakat Madura menyajikan sesuatu yang tentunya berbeda dari waktu ke waktu baik masyarakat Madura yang menetap di Pulau Madura sendiri maupun mereka yang ada di berbagai daerah di Indonesia atau 'Madura perantauan.' Masyarakat Madura dikenal sebagai masyarakat yang suka bermigrasi ke daerah lain karena faktor geografis Madura yang gersang. Komunitas Madura perantauan menyajikan sebuah permasalahan yang menarik, seperti adanya dominasi keberadaan simbol-simbol agama, patronase kyai, dan simbol agama lainnya sebagai wujud dari fanatisme agama masyarakat Madura.

Permasalahan tersebut menjadi menarik karena disaat berbagai masyarakat di Indonesia sudah mulai berubah oleh pengaruh modernisai dengan perubahan orientasi hidup dari komunal ke individual dan cenderung lebih materialistik, justru masyarakat Madura masih menikmati keberagamaan mereka sebagai kekayaan spiritual di tengah-tengah modernisasi. Mereka masih merasa nikmat berada dalam lingkar budaya paternalistik dengan kyai sebagai patron. Keadaan ini bisa bertahan untuk beberapa waktu yang sangat lama karena fenomena sosio-budaya masyarakat Madura masih berpusat pada figur kyai sebagai seorang tokoh karismatik. Sebagai figur karismatik, kyai didalam komunitas masyarakat Madura berkewajiban untuk menjamin keberlangsungan kehidupan sosial dalam masyarakat.

Berdasarkan fenomana diatas, penulis merasa tertarik untuk mengkaji pola hubungan kyai dan masyarakat di masyarakat Madura 
perantauan, Jember Jawa Timur. Pemilihan ini didasarkan pada realitas di masyarakat dimana mayoritas masyarakat di daerah ini terkesan menyerahkan persoalan baik kegamaan dan urusan duniawi ke kyai. Seperti halnya pemahaman tentang agama, perilaku politik dan penciptaan tradisi dan budaya dalam masyarakat. Sehingga peran kyai sangat dominan didalam beberapa segi kehidupan sosial masyarakat. Selain itu, salah satu alasan pemilihan tema ini dikarenakan belum banyak penelitian mengenai masyarakat Madura perantauan, khususnya mengenai hubungan mereka dengan para kyai atau guru. Salah satu fenoma yang dikaji dalam tulisan ini adalah ingin menguji kharisma dan daya kreatifitas kyai dalam dunia politik, khususnya dalam Pilihan Presiden 2004 dan Pemilihan Umum Daerah Kabupaten Jember 2005.

\section{Permasalahan}

Penelitian ini bermaksud untuk mengungkapkan peran kyai melalui karismanya dalam kehidupan sosial masyarakat Madura di Desa Sumber Wringin Jember Jawa Timur. Mitos-mitos dan unsur mistik masih mendominasi cerita-cerita kyai di masyarakat Madura dan oleh karena itu sangat menarik untuk dikaji. Fenomena tersebut memunculkan beberapa hipotesis tentang bagaimana fenomena tersebut bisa bertahan dan bagaimana perubahan sosial dalam masyarakat Madura mempengaruhi hubungan kyai dengan masyarakat Madura. Sehingga penelitian ini akan didasarkan pada dua pertanyaan yang seterusnya saya rumuskan kedalam dua rumusan penelitian. Pertama, penelitian ini dimaksudkan untuk menganalisis tentang bentuk-bentuk peran dan pengaruh kyai di kehidupan sosial masyarakat Madura Jember. Kedua, penelitian ini dimaksudkan untuk mengetahui alasan-alasan masyarakat Madura Desa Sumber Wringin Jember Jawa Timur untuk mematuhi kyai.

\section{Tinjauan Pustaka}

Horikhosi berpendapat bahwa kharisma merupakan wujud dari kualitas seseorang yang bisa mempengaruhi orang lain. Seseorang dianggap kharismatik jika dia bisa melakukan sesuatu yang orang lain tidak bisa melakukannya. Kualitas kepribadian, kemampuan 
intelektual, dan kemampuan supranatural bisa menjadi faktor-faktor seseorang mendapatkan karisma. Kekuatan mistik atau supranatural banyak dimiliki oleh kyai sehingga mereka dianggap sebagai wali. Menurut ahli ilmu-ilmu sosial, kharisma tidak bisa terjemahkan secara definitif. Horikhosi (1987: 213) berpendapat bahwa kharisma hanya bisa diamati dari sederetan kepribadian yang kuat, berpengaruh besar, tekun, sangat ekspresif, pemberani, tegas, penuh percaya diri, supel, berpandangan luas, dan tajam dalam pemikiran.

Kyai menjadi tokoh yang kharismatik berdasarkan beberapa kriteria yang berlaku di masyarakatnya. Meskipun di berbagai daerah di Indonesia mempunyai standar yang berbeda-beda, namun secara umum seorang kyai dianggap kharismatik jika mempunyai extra ordinary knowledge atau perilaku yang dianggap diluar kebiasaan manusia pada umumnya. Oleh karena itu seorang kyai sebenarnya adalah seorang ilmuwan yang menguasai sesuatu bidang agama atau beberapa bidang sekaligus. Lebih jauh, kyai lebih dekat sebagai pemikir dan sekaligus sebagai panutan umat atau kelompok pengikutnya karena mereka tidak hanya dianggap mumpuni dalam ilmu agama melainkan juga dianggap pandai dalam ilmu-ilmu lainnya.

Di Jawa Barat (sunda) orang memanggil ulama dengan ajengan, di wilayah Sumatera Barat di sebut buya, di Aceh dikenal dengan teungku, di Sulawesi Selatan dipanggil dengan nama tofanrita, di Jawa disebut dengan kyai dan di Lombok dikenal tuan guru (Jaiz \& Akaha, 2005: 30). Sedangkan di Madura Jember, ulama disebut dengan kyae. Jika diikuti nama orangnya, masyarakat Madura hanya mengambil kata depannya saja seperti misalnya ke Khotib, ke Wasil dan seterusnya. Meskipun dalam budaya Madura, kata ke juga bisa dipakai untuk menyebut orang biasa. Akan tetapi penggunaan ke bagi orang biasa dalam masyarakat Madura menunjukan penghormatan dari orang lain terhadap orang yang dipanggil.

Di masyarakat Madura dan Jawa, kyai yang dianggap mempunyai tingkat makrifat yang tinggi disebut sebagai wali. Gelar itu biasanya diberikan kepada ulama yang sudah mencapai tingkat tinggi dan memiliki kemampuan pribadi yang luar biasa. Hal ini 
untuk menunjukkan bahwa sang ulama tersebut mempunyai kekuatan spiritual yang tinggi (Ismail, 1977: 62). Kyai bisa diartikan dalam tiga pengertian dasar, yaitu seseorang yang memimpin pondok pesantren, seseorang yang ahli agama dan seseorang yang mengajar di masjid atau mushala (Rahman, 1995: 260). Beberapa kyai, selain aktif di pesantren juga aktif dalam kegiatan keagamaan di masyarakat. Dirjosanjoto (1999: 159) menyatakan bahwa kyai tidak bersifat ekslusif dan juga menjadi pemimpin lokal dari aktifitas keagamaan baik yang digagasnya sendiri maupun yang digagas oleh para pendahulunya.

Dari beberapa pengertian tersebut, kyai bisa diartikan sebagai seorang ilmuwan yang memiliki kemampuan spiritual yang tinggi, menjadi pemimpin institusi agama, mengajar santri dan masyarakat serta mempunyai pengikut setia dalam jumlah tertentu. Kemampuan kyai mengombinasikan kemampuan spiritual dan intelektual menyebabkan mereka menjadi tokoh yang dianggap kharismatik oleh pengikutnya.

Masyarakat Madura Jember secara histories mempunyai keunikan tersendiri. Hal ini disebabkan pola persebaran masyarakat Madura di Jawa Timur mayoritas berada di sepanjang Pantai Utara Jawa Timur mulai dari Surabaya, Sidoarjo, Pasuruan, Probolinggo, Situbondo, sampai Banyuwangi. Salah satu hasil dari penelitian Kuntowijoyo menunjukan bahwa pemukiman orang Madura di Jember sudah ada sejak tahun 1806 dimana Jember merupakan kabupaten yang mempunyai desa etnis Madura terbanyak, sebanyak 22 desa di Puger Jember Selatan. Sedangkan total populasi etnis Madura di pojok timur Jawa Timur sekitar 498.273.

Pada tahun 1840an, orang Madura sebenarnya tidak tertarik untuk bermigrasi ke Jember karena tidak adanya perusahaan perkebunan sebagai tempat kerja. Selain itu, Jember pada waktu itu hanya merupakan kota distrik dari afdeling Bondowoso yang sepi dan belum banyak hutan yang dibuka untuk perkebunan. Sehingga secara ekonomis, mereka tidak tertarik untuk bekerja dan menetap di Jember. Akan tetapi setelah dibukanya beberapa perusahaan perkebunan pada sekitar 1859an, migrasi orang Madura ke Jember meningkat dari tahun ke tahun. Faktor pendukung migrasi 
lainnya adalah dibukanya jalur kereta api dari Panarukan di Situbondo ke Jember melalui Bondowoso pada tahun 1897. Agaknya, faktor ekonomis ini menjadi alasan migrasi orang Madura yang banyak terdapat di Jember (Handayani, 1995).

Pada tahun saat penelitian ini dilaksanakan (2006), total populasi etnis Madura di Jember bisa dikatakan $1 \frac{1}{2}$ dari total populasi penduduk Kabupaten Jember. Total populasi penduduk Jember adalah sekitar 2.700.000,- orang dari berbagai etnis. Menurut Ayu Sutarto (2006), Jember pada dasarnya tidak mempunyai penduduk asli. Semuanya adalah pendatang dan kebanyakan dari mereka adalah etnis Madura dan etnis Jawa.

Semboyan dari pertalian persaudaraan sesama orang Madura adalah budaya tretan yang sangat terkenal. Teman dalam perspektif orang Madura diibaratkan sebagai saudara sendiri yang harus mendapat perlakukan seperti keluarga inti. Pertalian berdasarkan tretan ini bisa sampai mencapai empat keturunan. Artinya, hubungan berdasarkan tretan ini sama dengan pola hubungan kekerabatan yang ada di masyarakat Madura (Wiyata, 2002: 52). Keterkaitan seperti dalam konsep tretan tersebut didasarkan atas persamaan etnis, persamaan kepercayaan, yang mengakibatkan persamaan perilaku dan sikap. Kesadaran kolektif masyarakat ini kemudian membentuk sebuah jaring solidaritas sosial. Masing-masing individu dihubungkan oleh adanya saling ketergantungan yang terbatas pada bidang ekonomi dan komunikasi antar individu dalam masyarakat. Kekuatan dari jaring solidaritas tersebut ditentukan oleh seberapa besar ketergantungan individu tersebut. Lebih jauh, keterlibatan individu dalam masyarakat akan menentukan solidaritas yang ditimbulkan (Johnson, 1981: 182).

\section{Metode Penelitian}

Penelitian ini menggunakan metode penelitian kualitatif dengan deskriptif analisis untuk menggambarkan data di lapangan. Data disusun atas dengan menggunakan teori grounded dikarenakan hampir semua data yang dibutuhkan dalam tulisan ini ada di lapangan. Untuk mendapatkan data secara komprehensif, maka penulis menggunakan tiga macam pengumpulan data, yakni dept 
interviews, direct observation, dan written document (Patton, 1987: 7). Data dari dept interviews berasal dari pengalaman, pengetahuan, pendapat, dan perasaan informan tentang kyai yang menjadi objek penelitian. Informan dipilih berdasarkan kedekatan mereka dengan kyai dan intensitas keterlibatan mereka dalam aktifitas sosial keagamaan yang dipimpin oleh kyai seperti kyai-kyai, lora-lora, tokoh masyarakat, masyarakat, dan alumni Pesantren Roudlotul Ulum.

Data dari observasi terdiri dari deskripsi terdiri yang detail dari aktifitas program penelitian seperti perilaku partisipan dan semua interaksi dari responden sebagai bagian dari program experiences (Patton, 1987: 7). Observasi dalam penelitian ini dilakukan dengan cara observasi langsung dalam beberapa kegiatan atau participant observation seperti ikut dalam pengajian (Ritzer, 2004: 63). Selain itu, penulis juga melakukan observasi singkat yang biasanya penulis lakukan selama sehari penuh sehingga observasi ini termasuk dalam tipe observes as participant. Beberapa observasi yang dilakukan oleh penulis adalah observasi dari kegiatan rutin dan pengajian kyai di masyarakat. Selain itu, penulis juga melakukan observasi langsung hampir setiap hari di Pesantren Roudlotul Ulum yang menjadi tempat tinggal penulis selama melakukan penelitian.

Interview dan observasi diperlukan untuk memahami sudut pandang penduduk asli yang menjadi objek penelitian tentang kebudayaan mereka. Kemudian peneliti menginterpretasikan, mendefinisikan dan mendeskripsikan fenomena sosial tersebut dari sudut pandang orang dalam (Spradley, 1997: 5). Cara ini sangat diperlukan untuk menilai sebuah fenomena sosial dari sudut pandang yang paling dekat dengan realitas sosial yang menjadi objek penelitian. Spradley lebih jauh mengatakan bahwa peneliti harus melakukan proses pemahaman atas semua hal yang telah dia dapatkan dilapangan dan seterusnya menyimpulkannya dalam deskripsi tulisan. Kategori dan dimensi dari analisis muncul dari obeservasi sebagai evaluasi yang datang dari pemahaman kerangka program yang ada. Proses analisis dan interpretasi melibatkan studi yang disiplin, cara pandang yang kreatif, dan perhatian terhadap tujuan dari penelitian yang cermat (Spradley, 1997: 144).

Adapun data-data yang digunakan untuk mendukung thesis ini adalah data primer dan skunder. Data primer berasal dari interview 
dan observasi sedangkan data skunder berasal dari dokumen yang ada seperti dokumen dari Pesantren Roudlotul Ulum, institusi pemerintah setempat dan kepustakaan. Data dari institusi pemerintah yang dimaksud adalah data dari Komisi Pemilihan Umum kabupaten Jember, Departemen Agama Kabupaten Jember, Desa Sumber Wringin dan Kecamatan Sukowono. Data-data literatur yang diperoleh dari perpustakaan adalah laporan penelitian, jurnal, skripsi, thesis dan disertasi yang mendukung topik penelitian di Perpustakaan Universitas Jember dan Universitas Gadjah Mada.

\section{Pembahasan}

\section{a. Kharisma Kyai dalam Kebidupan Sosial Masyarakat}

Dalam masyarakat Islam kultural-tradisional seperti masyarakat Madura Jember, struktur sosial yang terbentuk adalah berupa kepemimpinan kharismatik dengan seseorang sebagai tokoh sentral yang umumnya dipegang oleh pemimpin komunitas yang dalam hal ini diperankan oleh kyai. Seseorang yang menjadi tokoh sentral harus mempunyai semua kemampuan yang dibutuhkan oleh masyarakat. Hal ini karena hubungan antar individu dalam masyarakat terbentuk oleh kesadaran kolektif dari individu-individu dalam masyarakat tersebut. Sehingga yang terjadi kemudian adalah sebuah potret kehidupan komunal dengan seseorang atau beberapa orang yang mewakili 'creative minority groups' sebagai pemimpin informal yang karismatik untuk tetap menjaga kelangsungan hidup masyarakat. Dalam konteks kehidupan sosial masyarakat Madura Jember, peran dari pemimpin informal tersebut dipegang oleh kyai sebagai figur sentral.

Kekaguman masyarakat atas kepribadian seorang kyai yang dianggap mumpuni dalam mengatasi konflik di masyarakat adalah faktor utama seorang kyai mendapatkan karisma dari masyarakatnya. Kemampuan ini menunjukan bahwa kyai memperhatikan dan mengerti realitas yang terjadi di masyarakat. Pada akhirnya kyai dituntut untuk bisa mengatasi rasa tertekan masyarakat dan mengubahnya menjadi semangat dan harapan. Kepercayaan ini membuat masyarakat merasa aman secara psikologis untuk terus berada dibawah hegemoni kharisma kyai. Kepemimpinan kyai 
dalam masyarakat tidak diukur dari cara hidupnya melainkan diukur dari pencapaiannya di bidang kehidupan sosial. Keberhasilan kyai untuk menghidupkan kembali sistem sosial ditengah konflik masyarakat menunjukan bahwa kyai dihormati masyarakat karena ia lebih besar dari kehidupannya atau meminjam istilahnya Gus Dur, larger than life (Anonim, 1999: 48). Istilah larger than life digunakan oleh Gus Dur untuk menggambarkan profil pemimpinpemimpin dunia yang berhasil membawa rakyatnya kearah yang lebih baik seperti Mahatma Gandhi, Mao Ze Dong dan MArthin Luther Jr. Pada akhirnya, kharisma kyai melahirkan hegemoni kekuasaan kyai atas masyarakat di semua bidang kehidupan masyarakat yang tidak saja terbatas pada agama melainkan juga merambah wilayah-wilayah publik lain seperti cara berpolitik dan melakukan rutinitas budaya yang ada dalam masyarakat.

Menurut Ayu Sutarto, kyai merupakan kelompok minoritas yang kreatif (creative minority) yang sangat berperan dalam setiap kehidupan sosial masyarakat. Mereka kreatif untuk terus memainkan perannya dalam kehidupan sosial masyarakat. Hal ini membuat wilayah kekuasaan kyai sebagai kelompok cerdik pandai dikonstruksi dari persepsi masyarakat akan kharisma mereka tidak saja sebagai spiritual leader melainkan juga sebagai village leader. Sehingga kyai sebagai figur yang berkarisma merupakan kekuatan revolusioner untuk mempertahankan tradisi dan budaya di masyarakat yang dianggap masih relevan dengan agama. Dengan kharismanya, kyai tidak hanya mampu menggalang kekuatan dari masyarakatnya melainkan juga menjalin relasi antar komunitas kyai itu sendiri. Dalam berbagai forum, kyai berusaha membangun dimensi horizontal dan vertikal dengan sesama kyai dan masyarakat. Sehingga tradisi dan budaya dalam masyarakat seperti tahlilan, silaturahmi, pengajian dan rutinitas keagamaan lainnya menciptakan relasi patronase antara kyai dan masyarakat.

Tradisi dan budaya seperti itu merupakan media aktualisasi kyai terhadap masyarakat karena pada dasarnya ada jarak yang memisahkan antara kyai sebagai patron dan masyarakat sebagai client. Masyarakat perlu mengetahui semua hal tentang kyai karena dia adalah seorang figur penting dalam masayarakat. Seperti misalnya KH Khotib dikenal oleh masyarakatnya sebagai seorang kyai yang 
pandai dalam ilmu agama dari rutinitas kegiatan yang diikutinya dalam masyarakat umum. KH Khotib Umar dalah pengasuh Pondok Pesantren Roudlotul Ulum, sebuah pesantren salaf yang berada di Desa Sumberwringin, Kecamatan Sukowono, yakni sebuah daerah yang terletak di sebelah timur laut Jember. Daerah ini berdekatan dengan perbatasan antara Jember dengan Bondowoso. Keteguhannya dalam memegang prinsip agama dan menjaga jarak dengan lingkungan politik mengakibatkan KH Khotib dihormati sebagai kyai yang berkarisma. Kepribadian KH Khotib yang teguh dan selalu berusaha untuk mengetahui realitas yang ada di masyarakat menjadikannya sangat akrab dengan masyarakat. Sehingga gagasan dan kegiatan dari KH Khotib yang ada di masyarakat selalu mendapatkan respon positif dari masyarakat luas. Beberapa tokoh masyarakat setempat berpendapat bahwa setelah masyarakat mengetahui kualitas kepribadian sang kyai, mereka menghormati sang kyai dan terus mengikuti semua jenis kegiatan yang diasuh oleh kyai sebagai bentuk penghormatan mereka.

Forum pengajian dan kegiatan agama lainnya adalah media penghubung antara kyai dan masyarakat setempat. Rutinitas-rutinitas keagamaan berguna bagi sang kyai untuk menjelaskan kepada masyarakat apa yang menjadi keinginannya. Selama tidak ada media seperti ini, kyai hanya memberikan isyarat dan masyarakat yang menafsirkannya. Isyarat seperti ini sangat sering dijumpai dalam dunia ke-kyai-an. Adanya jarak antara kyai pesantren yang ekslusif dengan masyarakat umum menjadikan rutinitas keagamaan sangat penting untuk menjelaskan relasi diantara keduanya dan juga untuk membaca alur pikiran kyai. Hal ini dikarenakan jarak yang ada antara kyai dan masyarakat membuat masyarakat tidak bisa secara langsung mengerti yang sebenarnya diinginkan oleh kyai. Masyarakat berusaha memahami isyarat yang diberikan oleh kyai dengan cara menafsirkan apa yang ada di balik isyarat dan pada akhirnya mereka akan mengikuti penafsiran melalui media-media perantara seperti kyai masjid dan tokoh masyarakat yang secara emosional dekat dengan sang kyai.

Pesantren sebagai institusi milik kyai juga berfungsi sebagai media transfer ilmu pengetahuan dan nilai-nilai sosial dari kyai kepada masyarakat. Nilai-nilai ini kemudian menyebar mengikuti 
pola persebaran alumni santri. Persebaran ini cenderung tidak merata dan terpencar tergantung dimana para alumni menetap. Namun yang menjadi ciri khas dari pola persebaran para alumni pesantren Madura seperti Pesantren Roudlotul Ulum ini hanya terbatas pada masyarakat Madura saja. Para alumni pesantren akan terus mengikuti dan meghormati kyai karena dia dipercaya bisa mengetahui rahasia Tuhan dan rahasia alam sehingga mereka mempunyai kedudukan sebagai penerjemah atas semua kejadian di dunia yang tak terbatas (Dhofier, 1982: 55). Keunggulan kyai dibidang keagamaan, kedudukan mereka sebagai intelektual desa dan pandangan masyarakat bahwa mereka mempunyai kekuatan spiritual yang melebihi masyarakat biasa telah menempatkan para kyai sebagai kelompok pemuka desa (Dirjosanjoto, 1999: 216). Bahkan posisi kyai di masyarakat Madura Jember telah mengungguli aparatur negara baik di tingkat desa, kecamatan maupun kabupaten. Kyai menerima kunjungan dari berbagai elemen masyarakat setiap hari dengan membawa permasalahan yang beragam.

Status kyai yang pada umumnya berada diatas aparatur negara disebabkan adanya budaya "Bappa Babu Guru Rato" di masyarakat Madura. Ungkapan tersebut masih relevan di masyarakat Madura Jember meskipun dalam implementasinya ungkapan tersebut telah mengalami pergeseran karena proses akulturasi dengan budaya Jawa. Ada beberapa arti dari ungkapan tersebut dimana ada masyarakat yang menganggap kyai sebagai rato, sebagian lagi menganggap kyai sebagai parjaji atau priyayi dan sebagian lagi menganggap kyai sebagai salah satu figur yang harus dihormati selain orang tua dan aparatur negara.

Makna dari ungkapan diatas tentang posisi kyai sebagai "rato" bagi orang Madura dikarenakan bahwa kyai adalah seseorang yang dianggap telah memberikan pencerahan dengan memberikan ilmu agama sebagai bekal kehidupan akhirat. Selain itu, kyai juga seringkali menjadi rujukan masyarakat atas hal-hal yang tidak mampu diselesaikan sendiri oleh masyarakat. Dari situ kemudian masyarakat sangat menghormati kyai yang dianggap telah menyelamatkan masyarakat dari permasahalan ummat. Kyai, menurut mereka adalah seorang guru yang mengajari bagaimana mereka bertingkah laku menurut koridor agama. Sehingga mereka menganggap orang tua 
hanya bertugas mendidik anak-anak, tetapi setelah dewasa mereka akan mencari seorang guru (agama) yang biasanya kyai untuk belajar ilmu (agama). Sehingga kyai adalah "rato" yang harus dihormati oleh orang Madura dibidang ilmu pengetahuan.

Makna lain dari ungkapan diatas adalah yang memosisikan kyai setelah orang tua dan sebelum rato atau pejabat negara. Pergeseran dari makna ungkapan ini sangat wajar karena akulturasi antara budaya Madura dan Jawa sudah terjadi berabad-abad lamanya. Meskipun demikian, realitas di lapangan bisa berbeda-beda tergantung dari kedekatan masyarakat dengan kyai. Masyarakat yang seringkali melakukan kontak langsung dengan kyai baik melalui pengajian rutin atau silaturahmi masih menganggap kyai sebagai figur guru yang harus diaati setelah orang tua. Sedangkan bagi masyarakat umum yang jarang bersinggungan dengan dunia ke-kyai-an tidak melihat kyai sebagai seorang guru.

Posisi kyai sebagai guru tersebut mengakibatkan masyarakat Madura mematuhi kyai melebihi dari pejabat. Hal ini didasarkan pada penempatan rato setelah guru. Melalui kyai sebagai guru, masyarakat Madura mempunyai pemahaman tentang agama melalui proses pengajaran dari kyai. Proses tranformasi bisa melalui pengajaran keagamaan seperti pengajian, majelis taklim dan dakwahdakwah. Bisa dikatakan bahwa kyai dalam konteks ini merupakan agent of social control. Pemahaman masyarakat akan suatu wacana ditentukan oleh kyai sebagai figur tunggal dalam proses tranformasi tersebut.

Yang ketiga adalah interpretasi dari ungkapan tersebut dimana masyarakat menganggap kyai sebagai rato. Kyai dianggap sebagai rato karena mereka dianggap tidak saja sebagai ahli dan pemuka agama melainkan juga mengatur perikehidupan sosial masyarakat. Menurut masyarakat, selain kyai memberikan pengetahuan tentang agama, kyai dalam beberapa kesempatan juga menggantikan peran aparatur negara di masyarakat. Oleh karena itu kemudian kyai diibaratkan sebagai rato yang bertugas mengatur kehidupan sosial masyarakat.

Bustami (2004) mengatakan bahwa pada dasarnya kepatuhan masyarakat Madura kepada kyai sebenarnya lebih pada tataran 
moralitas dan masalah-masalah ukhrowi (morality and sacred world). Akan tetapi pengetahuan masyarakat yang diperoleh dari kyai seperti rejeki dan pekerjaan adalah urusan Tuhan, maka hal ini mempengaruhi orientasi pemahaman masyarakat akan tujuan dari pendidikan itu sendiri. Urusan pendidikan agama berbeda dengan urusan pendidikan yang berorientasi kepada kesejahteraan materi. Masyarakat menganggap bahwa kesejahteraan tidak bersangkut paut dengan tinggi rendahnya pendidikan, melainkan berdasarkan keilmuwan dan keilmuwan tidak harus didapatkan dari sekolah formal. Mereka menggunakan analogi kesuksesan kyai dalam hal materi dengan lulusan sarjana yang banyak menganggur. Analogi ini dipakai oleh masyarakat untuk menjustifikasi bahwa anggapan masyarakat bahwa pendidikan berpengaruh terhadap kesejahteraan secara materi adalah kurang tepat.

Pendapat ini masih banyak terdapat di kalangan masyarakat Madura Jember, khususnya masyarakat santri. Kedekatan mereka dengan kyai membuat pemahaman masyarakat tentang pendidikan selalu mengacu kepada kyai. Sehingga tingkat kesadaran masyarakat akan pendidikan formal masih rendah. Mereka lebih memilih untuk belajar agama berdasarkan dalil dalam Al Quran yang menyatakan bahwa Tuhan akan menaikkan derajad hambanya yang berilmu.

\section{b. Kharisma Kyai Dalam Politik}

Kharisma KH Khotib di Masyarakat Madura Desa Sumber Wringin Jember ternyata masih dipercaya oleh elit politik untuk bisa mengumpulkan dukungan terhadap kepentingan politik mereka. Pendekatan yang dilakukan oleh elit politik kepada sang kyai bisa berupa silaturahmi atau meminta dukungan secara langsung. Silaturahmi "ala politikus" seperti ini efektif untuk menggalang massa arus bawah sebagai pengikut setia kyai. Elit politik melihat bahwa kharisma kyai bisa memunculkan hegemoni kyai sehingga sangat potensial untuk mengumpulkan dukungan terhadap kepentingan mereka. Masyarakat, cenderung tidak memikirkan siapa yang akan dipilih melainkan siapa yang didukung oleh kyai.

Elit politik yang datang kepada KH Khotib dalam peristiwa politik (pilpres 2004 dan pilkada Jember 2005) lalu adalah $\mathrm{KH}$ Salahuddin Wahid sebagai cawapres dari Wiranto yang didukung 
oleh PKB. Sedangkan dalam pilkada Jember 2005, elit politik yang datang adalah Samsul Hadi Siswoyo yang didukung oleh PCNU dan PKB Cabang Jember. Bahkan Samsul Hadi Siswoyo sebagai calon bupati Jember rela memberikan sebuah unit mobil dalam pilkada Jember 2005 lalu. Pada pilkada Jember 2005 lalu, calon bupati Samsul Hadi Siswoyo menyerahkan satu buah unit mobil avanza kepada KH Khotib. Meskipun dalam pernyataan Samsul bahwa mobil tersebut bukan didasari kepentingan politik, akan tetapi sumbangan mobil menjelang pilkada bisa diartikan sebagai bentuk pendekatan politik kepada sang kyai. Akan tetapi KH Khotib menegaskan tidak mendukung Samsul HS dalam pilkada Jember. Penolakan KH Khotib ini didukung oleh KH Wasil yang terangterangan melontarkan wacana "asal bukan Samsul."

Dalam kasus pilpres 2004 lalu, KH Khotib adalah salah satu kyai di Pesantren Roudlotul Ulum yang menjadi rujukan elit PKB. Meskipun kyai ini tidak mempunyai jabatan struktural, posisinya sebagai dewan ulama partai mempunyai pengaruh kuat dalam setiap keputusan eksekutif partai. Kyai juga dianggap sebagai kelompok elit lokal dalam struktur sosial politik yang mempunyai pengaruh kuat di masyarakat arus bawah. Posisi kyai sebagai figur penting di masyarakat desa membuahkan pengaruh yang melampaui batasbatas kekuasaan secara geografis (Dhofier, 1982: 56).

Pada pilpres putaran pertama, KH Khotib secara tidak terangterangan mendukung pasangan Wiranto-Wahid. Alasan beliau tidak mendukung pasangan Mega-Hasyim adalah karena sang kyai menolak pemimpin perempuan dalam Islam. Meskipun tidak ada pernyataan resmi dari sang kyai, masyarakat bisa menangkap isyarat bahwa sang kyai menjatuhkan pilihan ke pasangan tersebut. Hal ini bisa dilihat dari kunjungan $\mathrm{KH}$ Solahuddin Wahid sebagai cawapres dari Wiranto yang didukung oleh PKB ke kediaman $\mathrm{KH}$ Khotib di masa kampanye. Meskipun demikian, sang kyai tidak menganjurkan masyarakat di Desa Sumber Wringin untuk memilih pasangan tersebut. Akan tetapi dengan datangnya Wahid ke kediaman KH Khotib, masyarakat bisa membaca bahwa sang kyai mendukung pasangan tersebut.

Meskipun demikian, isyarat tersebut tidak diikuti oleh semua warga masyarakat Sumber Wringin yang mayoritas NU tersebut. 
Hal ini disebabkan oleh adanya dualisme instruksi mengenai calon mana yang harus dipilih. Secara struktural, ada instruksi dari PWNU Jawa Timur bahwa masyarakat NU di Jawa Timur harus memilih pasangan Mega-Hasyim. Pada saat itu, sikap PBNU bisa membingungkan warga Nahdliyin karena adanya perbedaan pendapat di kalangan kyai kultural dan kyai struktural. Misalnya, Rais AM PBNU KH Sahal Mahfud menyatakan bahwa sikap PBNU tetap netral dalam pilpres putaran I dan II. Hal ini didasari atas Khittah NU 1926 yang dihasilkan pada muktamar NU di Situbondo tahun 1984. sikap netral PBNU ini menyebabkan perbedaan di sikap di beberapa pengurus NU di wilayah. Salah satu contohnya adalah sikap yang diambil oleh PWNU Jawa Timur yang bersikap tegas mendukung pasangan Wiranto-Wahid. Secara kultural, kekuasaan kyai atas masyarakat menunjukan bahwa masyarakat harus memilih pasangan Wiranto-Wahid karena ada indikasi bahwa kyai memilih Wiranto-Wahid. Tak pelak dualisme wacana ini membuat masyarakat bingung menjatuhkan pilihannya. Tetapi perolehan suara pada pilpres putaran I di Desa Sumber Wringin dimenangkan oleh pasangan Wiranto-Wahid. Bahkan di TPS dekat Pesantren Roudlotul Ulum, perolehan suara Wiranto-Wahid menang mutlak. Daftar selengkapnya hasil perolehan suara pada pilpres pertama bisa dilihat dalam tabel I berikut ini:

\section{Tabel I}

\section{Daftar perolehan Suara Pemilihan Umum Presiden Wakil Presiden tahun 2004 di Desa Sumber Wringin (Sumber KPUD Jember)}

\begin{tabular}{clc}
\hline No & \multicolumn{1}{c}{$\begin{array}{c}\text { Daftar Nama Pasangan } \\
\text { Capres-Cawapres }\end{array}$} & Perolehan Suara \\
\hline 1 & $\begin{array}{l}\text { H. Wiranto, S.H. } \\
\text { Ir. H. Soluddin Wahid. }\end{array}$ & 2.447 \\
2 & $\begin{array}{l}\text { Hj. Megawati Sukarnoputri } \\
\text { KH. A. Hasyim Muzadi. }\end{array}$ & 80 \\
3 & $\begin{array}{l}\text { Prof. Dr. H. Amien Rais } \\
\text { Dr. Ir. H. Siswono Yudo Husodo. }\end{array}$ & 117 \\
4 & $\begin{array}{l}\text { H. Susilo Bambang Yudhoyono } \\
\text { Drs. H. Muhammad Jusuf Kalla. }\end{array}$ & 563 \\
5 & $\begin{array}{l}\text { Dr. H. Hamzah Haz } \\
\text { H. Agum Gumelar, M.Sc. }\end{array}$ \\
6 & Total & 77 \\
\hline
\end{tabular}


Dukungan secara tidak langsung dari KH Khotib terhadap pasangan Wiranto-Wahid ternyata banyak diikuti oleh masyarakat Desa Sumber Wringin. Kemenangan telak tersebut menunjukan bahwa jalan politik kyai juga diikuti oleh masyarakat karena selain percaya kepada pilihan kyai, mereka juga mencintai H. Solahuddin Wahid seperti Gus Dur. Masyarakat menganggap bahwa memilih Gus Solah sebagai adiknya Gus Dur sama dengan memilih Gus Dur.

Perbedaan jalan politik antara KH Khotib yang mendukung Wiranto-Wahid dengan PWNU Jawa Timur yang menghimbau kepada semua warga NU untuk mendukung Mega-Hasyim berimplikasi pada kebingungan warga NU. Akan tetapi wacana penolakan presiden perempuan yang dikemukakan oleh kyai berimplikasi pada merosotnya perolehan suara pasangan Mega-Hasyim. Masyarakat Madura sebagaimana warga NU lainnya memang secara organisatoris tidak terikat dengan organisasi manapun, tetapi secara kultural dan patriarkhal mereka terikat dengan organisasi tersebut. Masyarakat Madura cenderung lebih melihat figur daripada sistem organisatoris. Pada akhirnya masyarakat yang tidak memilih pasangan Wiranto-Wahid lebih memilih pasangan SBY-JK yang tidak mempunyai tradisi dengan kultur NU.

Salah satu tokoh masyarakat yang menghadapi kebingungan dalam menentukan pilihan politik adalah H.Yasin. Rumah H. Yasin tepat bersebelahan dengan Pesantren Roudlotul Ulum. Selain itu, dia masih memiliki sejarah kekerabatan yang sangat dekat dengan pihak pesantren karena latar belakang kakeknya yang menghibahkan tanah untuk pesantren. Kedekatan dia dengan kyai dan keberadaannya di kepengurusan NU membuat $\mathrm{H}$. Yasin harus menjatuhkan pilihan politiknya kepada pasangan Mega - Hasyim. Dia adalah salah satu fungsionaris di Ranting NU Sumber Wringin dan mantan fungsionaris PKB Ranting Sumber Wringin periode 1999 - 2004. Menurut pengakuannya, semua pengurus NU mulai dari pusat sampai ke ranting diinstruksikan untuk memilih pasangan MegaHasyim. Padahal H. Yasin sebagai partisan dan mantan fungsionaris PKB Desa Sumber Wringin harus memilih pasangan Wiranto-Wahid. Akan tetapi instruksi dari PWNU Jawa Timur mengharuskan dia untuk memilih Mega-Hasyim. Akhirnya pilihan politiknya jatuh kepada pasangan Mega-Hasyim. Alasanya karena instruksi dari 
PWNU adalah bersifat definitif untuk memilih Mega-Hasyim daripada isyarat yang diberikan oleh $\mathrm{KH}$ Khotib untuk memilih WirantoWahid. Isyarat dari KH Khotib ditafsirkan hanya bersifat fakultatif karena sang-kyai tidak pernah mengatakan kepada masyarakat untuk memilih Wiranto-Wahid. Sedangkan instruksi dari PWNU Jawa Timur besifat mengikat karena ada maklumat dari pimpinan.

Jika dalam pilpres putaran I KH Khotib hanya memberikan isyarat, pada pilpres putaran II, KH Khotib memberikan dukungan secara terang-terangan dimuka umum bahwa sang kyai mendukung pasangan SBY-JK. Agaknya dukungan ini menjadi sejarah tersendiri di Pesantren Roudlotul Ulum. Dalam sejarah Pesantren Roudlotul Ulum, kyai dilarang untuk memberikan dukungan ataupun terlibat aktif di politik praktis. Kenyataanya KH Khotib sendiri pernah mengeluarkan statemen yang menyatakan bahwa beliau dilarang oleh KH Umar untuk terlibat aktif dalam perpolitikan. Paradigma larangan berpolitik sudah mulai berubah seiring dengan perubahan dalam dunia ke-kyai-an di Pesantren Roudlotul Ulum. Sebelumnya $\mathrm{KH}$ Khotib hanya menerima silaturahmi dari elit politik dan mendoakan semoga proses politik berjalan lancar.

Ada faktor yang lebih utama mengapa KH Khotib secara terang-terangan mendukung pasangan SBY-JK dalam pilpres II yaitu wacana penolakan pemimpin perempuan. Dukungan KH Khotib terhadap pasangan SBY-JK merupakan salah satu cara untuk menghadang pasangan Mega-Hasyim karena beliau memang menolak pemimpin perempuan. Selain itu, pilihan politik ini mengindikasikan adanya pembelotan politik dari KH Khotib atas perintah dari PWNU Jawa Timur untuk memilih pasangan Megahasyim. Hal ini didasarkan atas realita bahwa KH Khotib adalah salah satu pengurus PWNU Jawa Timur dan sebagai wakil syuriah PCNU Jember. Akan tetapi sebagai salah satu kyai khos di NU dan $\mathrm{PKB}$, ternyata $\mathrm{KH}$ Khotib tidak memilih pasangan yang didukung oleh PWNU. Alasan kyai untuk lebih memilih pasangan SBY-JK adalah adanya wacana tidak diperbolehkannya memilih pemimpin perempuan. Khilafah tentang diperbolehkannya pemimpin perempuan dalam Islam sudah lama berlangsung. Sehingga wajar jika KH Khotib mempunyai ijtihad sendiri untuk tidak memilih pasangan Mega-Hasyim. 
Kenyataan politiknya, kharisma Hasyim Muzadi sebagai ketua PBNU ternyata tidak mampu melawan kharisma kyai arus bawah seperti KH Khotib. Kedekatan KH Khotib kepada masyarakat Desa Sumber Wringin menjadi salah satu faktor kekalahan pasangan Mega-Hasyim di Sumber Wringin. Selain itu, masyarakat yang tinggal di pedalaman desa lebih mengenal nama KH Khotib Umar daripada nama KH Hasyim Muzadi. Hal ini menyebabkan pasangan SBY-JK mendapatkan limpahan suara dari pasangan Wiranto-Wahid pada putaran I lalu. Oleh sebab itu, pada pemilu pilpres putaran II ini pasangan SBY-JK yang didukung secara terang-terangan oleh sang kyai menang mutlak di lingkungan Sumber Wringin. Selengkapnya lihat tabel II.

\section{Tabel II}

\section{Perolehan suara pada Pilpres II di Desa Sumber Wringin}

(Sumber: KPUD Jember)

\begin{tabular}{clc}
\hline No & \multicolumn{1}{c}{ Nama Pasangan Calon } & $\begin{array}{c}\text { Jumlah Perolehan } \\
\text { Suara }\end{array}$ \\
\hline 1 & $\begin{array}{l}\text { Hj. Megawati Sukarnoputri } \\
\text { KH. A. Hasyim Muzadi }\end{array}$ & 372 \\
2 & $\begin{array}{l}\text { H. Susilo Bambang Yudhoyono } \\
\text { Drs. H. Muhammad Jusuf Kalla } \\
\text { Total }\end{array}$ & 2.791 \\
\hline
\end{tabular}

Peningkatan suara pasangan SBY-JK yang signifikan menunjukan bahwa dukungan KH Khotib terhadap pasangan ini diikuti oleh masyarakat. Berbeda dengan isyarat dari kyai di pilpres putaran I yang ditafsirkan fakultatif, dukungan secara terang-terangan ini mengakibatkan masyarakat tidak ragu lagi dalam menentukan pilihan politiknya. Jika dilihat dari perolehan suara, hampir semua pemilih Wiranto-Wahid memilih SBY-JK. Keputusan warga Nahdliyin untuk tidak memilih Mega-Hasyim merupakan konsekuensi dari wacana penolakan pemimpin perempuan yang dilontarkan oleh KH Khotib.

Tentu saja sikap politik masyarakat yang mengikuti jalan politik kyai ini menjadi legitimasi kharisma $\mathrm{KH}$ Khotib dan melanggengkan tradisi kyai sebagai elit lokal. Sudah menjadi budaya di masyarakat santri bahwa mereka lebih mengenal dan mematuhi 
perintah dari kyai mereka daripada perintah dari PBNU. Bahkan banyak dari mereka yang tidak mengenal kyai-kyai yang duduk dijajaran struktural PBNU seperti Farid Mas'udi, Sahal Mahfud, dan fungsionaris lainnya. Sebelum Gus Dur menjadi Presiden, banyak masyarakat desa yang tidak mengenalnya. Mereka lebih kenal $\mathrm{KH}$ Khotib Umar daripada Gus Dur. Ternyata fenomena ini juga berlaku di kebanyakan masyarakat lain yang tidak mengenal Hasyim Muzadi sebagai ketua PBNU. Selain faktor media elektronik dan surat kabar yang masih kurang, rendahnya minat politik dan problem pendidikan masyarakat menjadi penyebab ketidaktahuan mereka akan situasi nasional. Hanya mereka yang dekat dengan kyai atau pejabat saja yang mengetahui realita di tingkat nasional.

Problematika sosial masyarakat ini menjadi salah satu faktor lenggengnya kharisma kyai di masyarakat. Karena kyai merupakan salah satu kaum cerdik pandai yang bisa melakukan transformasi pengetahuan kepada masyarakat yang pada akhirnya situasi ini akan melestarikan kekuasaan kyai atas masyarakat tersebut. Jalan politik kyai yang pada dasarnya bersebarangan dengan NU dinilai sebagai kebebasan kyai yang berpredikat sebagai kaum cerdik pandai di masyarakat. Mereka menganggap bahwa dalam sistem demokrasi, semua orang bisa memilih dengan bebas tanpa ada unsur paksaan dari siapapun. Pernyataan ini sebenarnya bersifat paradoks jika melihat perilaku politik masyarakat yang cenderung mengikuti perintah dari atas secara organisatoris. Mereka terbelenggu oleh sistem dan tradisi yang tanpa disadari telah mengekang hakhak politik masyarakat. Dilain pihak, kyai sangat leluasa untuk melakukan pembelotan-pembelotan politik dengan dalih sebagai kaum cerdik pandai dalam masyarakat.

Selain itu, juga ada fakta yang berbeda mengenai perilaku politik kyai dengan masyarakat. Masyarakat sebagai arus bawah menunggu perintah dari organisasi formal dan isyarat dari kyai yang bersifat informal. Masyarakat arus bawah yang menjadi bagian dari organisasi tersebut akan mengikuti garis politik lembaga atau memilih untuk mengikuti isyarat kyai. Akan tetapi tidak demikian dengan kyai yang cenderung lebih bebas untuk menentukan pilihan politiknya. Hal ini didasarkan pada persepsi masyarakat bahwa kyai sudah mempunyai ijtihad tersendiri. Mereka diyakini mampu 
melakukan ijtihad politik tanpa bimbingan dari siapapun. Setiap tindakan politik kyai adalah benar dalam pandangan masyarakat awam. Karena mereka berkeyakinan jalan politik kyai mempunyai dasar pemikiran yang matang.

\section{c. Majmuk Al Babroini}

Keterlibatan kyai dalam politik sampai sekarang masih menjadi perdebatan. Namun sebenarnya langkah politik kyai tidak perlu dibesar-besarkan karena keterlibatan kyai dalam politik sudah berlangsung sejak lama. Kyai yang memutuskan untuk berpolitik mempunyai dasar yang kuat, yakni berdasarkan kisah keteladanan Nabi Khidir, seorang nabi yang mempunyai sejarah dan kisah istimewa melalui majemuk al bahroini. Arti literer dari majmuk al bahroini adalah berdiri diantara dua samudera. Tidak ada seorangpun yang mencela perbuatan Nabi Khidir ketika dia diceritakan membunuh seorang anak laki-laki karena kelak anak tersebut akan berbuat kerusakan. Majemuk Al Bahroini yang digunakan oleh Nabi Khidir untuk membela perbuatannya kemudian dijadikan dasar perilaku politik.

Kata ini diucapkan Nabi Khidir ketika dia ditanya oleh seseorang setelah dia membunuh seorang anak laki-laki. Nabi Khidir kemudian menjawab bahwa kelak setelah dewasa, anak ini akan membunuh orang tuanya sehingga dia harus membunuhnya. Membunuh dalam Islam adalah sebuah tindakan yang dilarang, akan tetapi keputusan Nabi Khidir untuk menyelamatkan orang tua dari anak ini menempatkan dia dalam dua sisi, melakukan pembunuhan dan sekigus melakukan penyelamatan yang lebih besar. Nabi Khidir berada di dua dunia ketika dia melakukan pembunuhan, yaitu dunia nyata dengan melakukan kejahatan berupa pembunuhan dan dunia masa depan yaitu melakukan penyelamatan yang lebih besar.

Dalam sejarahnya, kyai dianggap memanfaatkan situasi dengan menjadi oportunis untuk mendekati penguasa. Menurut Hindley, para politisi NU termasuk kyai adalah sekumpulan pemimpin yang amatiran dalam berpolitik, oportunis dengan hanya mencari keuntungan pribadi. Isyarat yang sering dilakukan oleh kyai agaknya tidak mampu dibaca dan diterjemahkan oleh orang 
luar. Hanya komunitas kyai saja yang bisa menerjemahkan arti dari isyarat politik yang diberikan oleh kyai.

Majemuk al bahroini sebagai pijakan dasar perilaku politik kyai sebenarnya merupakan politik pembelajaran kepada masyarakat. Kyai sebagai pemimpin umat harus tetap menjadi figur tunggal dalam urusan agama. Fungsi kyai sebagai spiritual leader masyarakat harus tetap netral dalam aktifitas politik apapun. Akan tetapi untuk merepresentasikan politik massa NU, kyai sebagai satu-satunya elit lokal harus mewakili aspirasi masyarakatnya. Kyai sebagai salah satu pihak yang mempunyai kekuasaan informal atas masyarakatnya harus mengakomodasi politik warga Nahdliyin agar tidak dimanfaatkan oleh pihak lain. Karena dalam sejarah politik NU, warga Nahdliyin seringkali hanya dimanfaatkan untuk dijadikan pengumpul suara tanpa menerima jatah kekuasaan secara proporsional.

Akibat dari langkah politik kyai untuk melakukan dua hal yang bersebarangan tersebut menyebabkan kyai mempunyai peran ganda dalam masyarakat yaitu peran dalam urusan profane dan sacred. Peran kyai dalam ruang profane adalah dengan terlibat dalam ruang-ruang politik dengan tujuan untuk mencapai suatu tujuan tertentu. Keputusan kyai untuk berpolitik adalah untuk melakukan kemaslahatan bagi umat yang lebih besar dengan mengakomodasi aspirasi masyarakat yang selama ini dianggap hanya dijadikan alat pengumpul suara. Sedangkan peran kyai dalam ruang yang sacred adalah tetap menjadi spiritual leader dalam masyarakatnya. Berdiri di dunia ruang yang berbeda ini mengakibatkan posisi dan fungsi kyai dalam masyarakat menjadi pendukung atas legitimasi kyai dalam politik dan agama. Sebagai pemimpin politik, karisma kyai bisa mengakibatkan sebuah gerakan sosial masyarakat yang berdasarkan solidaritas yang sangat luas dari para pengikutnya.

Boleh tidaknya kyai untuk terlibat dalam politik praktis merupakan khilafah diantara para ulama. Khilafah ini lebih dititik beratkan pada peran kyai tersebut sebagai pemimpin ummat yang mengurusi urusan ukhrowi, bukan sebagai pemimpin politik yang bersifat duniawi. Ada kekawatiran dari kyai yang tidak berpolitik bahwa politik yang selalu berujung pada menang dan kalah bisa mempengaruhi kredibilitas dan posisi kyai dalam masyarakat. Bahkan di lingkungan Pesantren Roudlotul Ulum pun khilafah ini 
menjadi faktor demokrasi antar kyai. Contohnya adalah KH Khotib Umar yang harus terlibat dalam politik karena alasan menolak pemimpin perempuan.

\section{Kesimpulan}

Faktor kharisma kyai merupakan salah satu sumber kekuatan dalam menciptakan pengaruh di dalam masyarakat yang masih berada dalam budaya paternalistik dimana hirearkhi kekuasaan berpusat pada figur kyai. Kharisma KH Khotib dan kyai-kyai lainnya di masyarakat Madura Desa Sumber Wringin Jember sangat ditentukan oleh kemampuannya untuk bisa membawa rasa aman di masyarakat. Kepribadian yang kuat dan mampu mencari jalan keluar dalam mengatasi macetnya sistem sosial masyarakat adalah salah satu faktor penting dalam membentuk kharisma. Kyai dianggap bisa mengatasi kemacetan sistem sosial yang seringkali mengakibatkan situasi chaos dalam masyarakat dan mengancam struktur sosial dan tradisi dalam masyarakat.

Kemampuan kyai untuk menjawab semua persoalan masyarakat baik yang bersifat individual maupun komunal menyebabkan masyarakat sangat yakin terhadap penyelesaian yang dilakukan oleh sang kyai. Oleh karena itu, semua gagasan kyai seperti acara pengajian dan ritual-ritual agama lainnya yang dipimpin oleh sang kyai selalu dihadiri oleh masyarakat sebagai tanda ketertundukan mereka kepada kyai tersebut. Pola hubungan yang tercipta diantara kyai dan masyarakat adalah pola hubungan interdependensi. Masyarakat memerlukan seorang figur yang dipercaya bisa mengatasi masalah sedangkan kyai memerlukan masyarakat sebagai media untuk berkatualisasi sebagai bagian dari kelompok minoritas kreatif. Masyarakat menganggap kyai adalah seseorang yang bisa memberikan rasa aman secara emosional bagi masyarakat untuk mengenali jati diri mereka sebagai kelompok sosial.

Kharisma kyai dalam politik bisa dilihat dari peristiwa politik yang ada. Beberapa kyai mempunyai pengaruh yang besar dalam mempengaruhi kehidupan politik masyarakat meskipun para kyai tersebut tidak terlibat langsung dalam politik praktis. Peristiwa politik seperti Pilpres 2004 menunjukan bahwa masyarakat akan mengikuti 
jalan politik kyai yang dianggap paling kharismatik. Mereka merasa yakin bahwa apa yang dikatakan oleh kyai adalah benar dan harus diikuti meskipun tidak ada perintah langsung dari kyai yang bersangkutan untuk mengikuti jalan politik mereka.

Perilaku politik masyarakat tradisional masih berdasarkan religi, kultus terhadap seseorang dan didasari atas solidaritas sosial berbasis agama. Kehidupan masyarakat yang komunal memungkinkan terjalinnya hubungan antar individu berdasarkan kepentingan bersama. Jika demikian, politik yang ada di masyarakat sebenarnya adalah suara tunggal masyarakat tersebut yang berasal dari salah satu figur paling kuat. Figur tersebut mempengaruhi pola pikir masyarakat dan menggerakan mereka atas dasar kepatuhan komunal. Sehingga perilaku politik masyarakat berada dibawah hegemoni kekuasaan kyai sebagai figur sentral dalam masyarakat tersebut. Apa yang menjadi jalan politik kyai sebagai patron akan diikuti oleh masyarakat sebagai clien.

Dinamika politik masyarakat Desa Sumber Wringin merupakan contoh betapa figur seorang kyai mampu untuk memobilisasi massa tidak hanya pada tataran ukhrowi melainkan juga menyangkut masalah duniawi seperti politik. Dinamika politik masyarakat tidak pernah lepas dari hegemoni kyai yang tidak saja menjadi pemimpin agama melainkan juga aktif di perpolitikan lokal dan nasional. Sejarah perpolitikan masyarakat mengikuti liku-liku perpolitikan kyai dalam masyarakat tersebut. Meskipun ada beberapa masyarakat yang bisa melepaskan diri mereka dari hegemoni politik kyai. Itupun biasanya dilakukan oleh masyarakat umum yang mempunyai hubungan dengan kyai sangat rendah atau mereka yang terikat dengan organisasi sosial keagamaan. Sedangkan bagi masyarakat santri, perilaku politiknya masih selalu dibawah bayang-bayang hegemoni kyai.

\section{Daftar Pustaka}

, 1999. Gus Dur Menjawab Perubahan Sosial, Kumpulan Pemikiran KH Abdurrabman Wabid Presiden ke-4 Republik Indonesia. Kompas: Jakarta.

Bustami, Abdul Latief. 2004. "Madura yang Patub (kajian antropologi mengenai Budaya Madura). Kritik wacana” Center 
for Research on Inter-group Relation and Conflict Resolution. Ceric. UI: Jakarta. 02 Maret.

Dhofier, Zamakhsyari. 1982. Tradisi Pesantren, Studi tentang Pandangan Hidup Kyai. LP3S: Jakarta.

Dirjosanjoto,Pradjarta. 1999. Memelihara Umat Kyai Pesantren-Kyai Langgar di Jawa. LKiS: Jogjakarta.

Feally, Greg. Ijtihad Politik Ulama Sejarah NU 1952 - 1967. LKiS: Jogjakarta.

Handayani, Sri Ana. 1995. Etos Kerja Wanita Madura di Jember, Suatu Kajian Historis. Makalah Seminar: Jogjakarta.

Horikhosi. Hiroko. 19887. Kyai dan Perubahan Sosial. P3M. Jakarta. Ismail, Ibnu Qoyim. 1977. Kyai Penghulu Jawa Peranannya di Masa Kolonial. Gema Insani Press: Jakarta.

Jaiz, Hartono Ahmad \& Akaha, Zulfikar Abduh. 2005. Bila Kyai DiperTubankan, Membedah Sikap Agama NU. Pustaka Al Kautsar: Jogjakarata.

Jaiz, Hartono Ahmad. 2003. Bila Kyai di PerTuhankan, Membedah Sikap Politik NU. Pustaka Pelajar: Jogjakarta.

Johnson, Doyle Paul. 1981. Teori Sosiologi Klasik dan Perspektif Kontemporer. PT Gramedia: Jakarta.

Kuntowijoyo. tt.Madura, Perubahan Sosial dalam Masyarakat Agraris 1850-1940. Mata Bangsa: Jogjakarta.

Patton, Michael Quinn. 1987. How To Use Qualitative Method in Evaluation. Sage Publication: California.

Rabman, Bustami. 1995. Nilai Kultural dan Differensiasi Agraria di Pedesaan Jawa (Kasus Desa Lumbung Kerep di Jawa Tengah dan Desa Tamping Mojo di Jawa Timur). Disertasi. Universitas Gadjah Mada: Jogjakarta.

Ritzer, George. 2004. Sosiologi Ilmu Pengetahuan Berparadigma Ganda. PT Raja Grafindo. Jakarta. Spradley. James P. 1997. Metode Etnografi. PT. Tiara Wacana: Jogjkarta.

Sutarto, Ayu. 2006. Melacak Perjalanan Jember Dari Waktu Ke Waktu. Makalah seminar. Forsigana Universitas Jember. 20 April.

Turmudi, Endang. 2003. Perselingkuhan Kyai dengan Kekuasaan. LKiS: Jogjakarta.

Wiyata, A Latief. 2002. Carok: Konflik Kekerasan dan Harga Diri Orang Madura. LKiS: Jogjakarta. 